Article

\title{
Food and Nutrition Education against Overweight in School-age Children: A Scoping Review of progress in Spanish-speaking Countries
}

\author{
Angélica Lizárraga-Quintero ${ }^{1}$, Luisa Ortega ${ }^{1}$, Flavia Fontes ${ }^{1}$, Victoria Valdés ${ }^{1}$, Alex Brito ${ }^{2,3}$, Roberto Ávila ${ }^{4}$, \\ Stephen R. Kodish ${ }^{5}$, and Israel Ríos-Castillo ${ }^{1,6 * \mathbb{B}}$
}

1 University of Panama, Faculty of Medicine, School of Nutrition and Dietetics, Panama City, Panama; angelicalizarraga11@gmail.com (A. L-Q.), lortega9630@gmail.com (L. O.), flabran@hotmail.com (F. F.), victoria.valdes@up.ac.pa (V. V.), israel.rios@up.ac.pa (I. R-C.)

2 Laboratory of Pharmacokinetics and Metabolomic Analysis, Institute of Translational Med-icine and Biotechnology, I.M. Sechenov First Moscow State Medical University, Moscow, Russia; abrito@labworks.ru (A. B.)

3 World-Class Research Center "Digital Biodesign and Personalized Healthcare", I.M. Se-chenov First Moscow State Medical University, Moscow, Russia; abrito@labworks.ru (A. B.)

4 Instituto de Ciencias Básicas e Ingeniería, Universidad Autónoma del Estado de Hidalgo. Pachuca de Soto, México; ravila@uaeh.edu.mx (R. A.)

5 Department of Nutritional Sciences and Biobehavioral Health, Pennsylvania State Univer-sity. University Park, United States; quk80@psu.edu (S. R. K.)

6 Food and Agriculture Organization of the United Nations (FAO). FAO Subregional Office in Mesoamerica. Panama City, Panama; Israel.Rios@fao.org (I. R-C.)

* Israel.Rios@fao.org; Tel: +507 6581-9767. Food and Agriculture Organization of the United Nations (FAO). FAO Subregional Office in Mesoamerica. Panama City, Panama

\begin{abstract}
Background: School-aged children may benefit from education interventions focused on healthy eating and physical activity to improve their quality of life. Objective: To review the available scientific evidence on food and nutrition education (FNE) in Spanish-speaking countries for the prevention of excess weight in school-aged children (6-12 y). Methods: Relevant evidence was searched between April and August 2021. The searches were conducted using MEDLINE, Google Scholar, and SciELO. The primary search for articles focused on the experience of FNE interventions in Spanish-speaking countries. Results: Overall, 518 articles were found and 33 studies were eligible for data extraction. Forty two percent of the studies had a focus on FNE and 64 percent were focused on describing the eating habits of schoolchildren. Nutritional assessments (anthropometric) were found frequently with 91 percent and 30 percent of the studies focused on physical activity. All interventions focused on preventing or reducing overweight and obesity in school-age children. Educational, cognitive, dietary and physical activity practices were described, being educational the most frequent intervention. Conclusion: Interventions reported positive effects of FNE interventions to improve knowledge and practices of healthy lifestyles in school-age children.
\end{abstract}

Keywords: kEducation; effectiveness; intervention; food and nutrition education; knowledge; schoolchildren

\section{Introduction}

The term overweight is used to refer to an excessive increase in body fat that poses health risks [1]. The increase in overweight and obesity in school-age children (6-12 years) is worrying, due to its increase in recent years both in emerging and developing economies. Globally, 340 million children and adolescents are overweight [1]. Latin America and the Caribbean and other Spanish-speaking countries faces serious challenges to reduce overweight in schoolchildren, where the problem reaches up to 40 percent of school-age children [2]. 
Many countries are moving through the nutrition transition with increased urbanization, a growing economy, and changing food environments. As a result, negative changes in eating habits and a predominantly sedentary lifestyle are becoming the primary causes of overweight in the population [3]. Furthermore, the changing food environment, contaminated by advertising, promotion, and sponsorship of ultra-processed products and sugary drinks, directly influences the adoption of inappropriate food practices [4].

Customized food and nutrition education (FNE) is one intervention modality that may benefit for school-age children to learn about proper eating habits and healthy lifestyles [5]. School-age children may benefit from educational interventions on health and nutrition to change and improve lifestyles. In school settings, children are a captive audience ready to gain new information and skills that they may not be able to learn at home or in their communities. Children must acquire knowledge around healthy eating at an early age to give them the cognitive tools needed to prevent or treat overweight and obesity [6]. Therefore, it is necessary to involve all actors at all levels, i.e. school, community, and home. Thus, teachers are important agents to promote the health and nutrition habits of school-age children in schools so that they can transfer competencies and skills on healthy eating habits when they leave the school setting and enter adulthood [7].

The literature suggests that a lack of knowledge, together with an unfavorable attitude about healthy eating habits and an obesogenic environment, among other factors, affects the dietary habits of school-age children with health consequences [8]. It is during childhood that most people solidify their nutrition behaviors and lifestyle habits [9]. Children may grow up with inadequate eating habits if they never learned it at an early age [2].

Therefore, understanding how effective the implementation of FNE in schools has been important for developing future interventions aiming to improve healthy eating habits and lifestyles of school-aged children [8]. Likewise, understanding how the participation of parents, teachers and the entire educational community may influence child diets may inform future interventions, in consideration physical environments where dietary practices are carried out $[10,11]$. Given the rising number of interventions targeting overweight and obesity among school-aged children, we conducted this review to summarize the available evidence of FNE for the prevention of overweight in school-age children (6-12 years of age). We sought to answer the following two research questions during this review:

Research question 1: What are the types of FNE intervention approaches being used to improve nutrition outcomes among school-aged children?

Research question 2: What are the types of outcomes measured in FNE interventions aimed at school-aged children 6-12 years old? .

\section{Materials and Methods}

This paper presents findings from a scoping review of progress in Spanish-speaking countries of the available evidence on FNE interventions at schools to prevent overweight among school-age children. A comprehensive search for studies was carried out between April and August 2021. Articles related to FNE programs or that had in their title some of the descriptors of interest were selected. The study was carried out by the Nutrition and Dietetic School of the University of Panama.

\subsection{Inclusion and exclusion criteria}

Articles published in Spanish-speaking countries between 2015 and 2021 related to FNE programs aimed at primary school-age children (6 to 12 years old) were included. 
Community-level or clinical studies were excluded.

\subsection{Search strategy}

Our search included all studies that were observational, descriptive, analytical, crosssectional, cohort studies, cases and controls studies, pre-post-interventions, quasi-experimental intervention designs, with or without a control group, and randomized and double blindtrials. For the selection of studies, a search was conducted using MEDLINE PubMed, Google Scholar, and SciELO. Descriptive keywords such as: "food and nutrition education", "nutrition education", "knowledge", "loss weight", "school age", "behavior", "eating habits", "physical activity", and "cognitive" were used.

Titles and abstracts of initially identified articles were screened. Eligible studies were reviewed in full text and each article was checked for inclusion criteria to be selected for data extraction. The information that was extracted included: authors, year of publication, place of execution of the study, objectives, sample size, description of the intervention, summary of results, and conclusions.

\subsection{Ethical considerations}

The present scoping review was performed in the context of the project titled "Multisectoral public policy against obesity in primary school children in Panama, ISRCTN: 28920505". The Bioethics Committee of the University of Panama reviewed and approved the main project ( $\left.\mathrm{N}^{\circ} \mathrm{CBUP} / 075 / 2019\right)$. Details of the present scoping review were registered in the Open Science Framework platform: https://doi.org/10.17605/OSF.IO/85NAU.

\section{Results}

Table 1 shows the summary of available evidence from the selected studies on FNE against overweight in school-age children. Five hundred and eighteen studies were initially identified being 402 articles excluded because they were not related to the research objectives, leaving a total of 116 articles. Seventy-one studies were excluded due to duplication. Twelve articles were excluded because were made in non-Spanish-speaking countries. A total of 33 studies were included for the final extraction of information (Figure 1). 

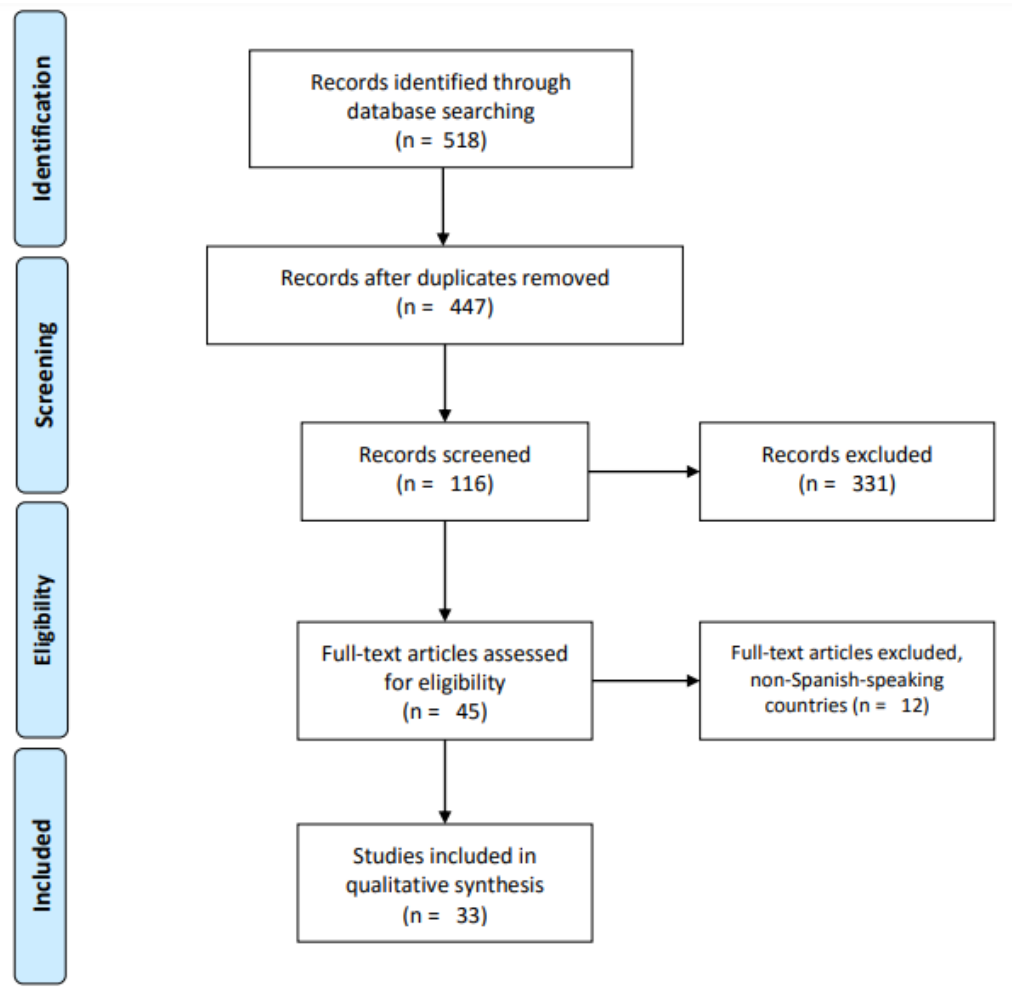

Figure 1. PRISMA flowchart of selected articles.

\subsection{Types of intervention approaches used FNE studies}

Most of the FNE studies intervened through evaluations of eating habits in 63 percent (21/33), followed by educational programs (42 percent (14/33) of the studies). Nutritional assessments (anthropometric) were included in 91 percent $(30 / 33)$ and 30 percent $(10 / 33)$ of the studies included physical activity as an outcome. The identified FNE interventions were focused on both physical activity programs and educational activities for schoolchildren. Compared to other study designs, the intervention studies had a focus on preventing and reducing overweight or obesity in participants.

In the transformation of healthy schools, the FNE intervention was carried out with the school-age children, teachers, and administrative personnel of the schools to achieve changes at the level of the physical structure and the environment, to support the measures of prevention of overweight. In these, they managed to improve the school environment through illustrative posters with health messages or advice throughout the school. In others, they painted the stairs and corridors of the schools to promote physical activity among students. They also focused on improving school canteens, that is, having better options in the food supply, above all suspending the sales of processed foods and sugary drinks, and thus providing and encouraging students to prefer healthy foods, as also reported elsewhere $[44,45]$.

On the other hand, concerning counseling on physical activity and nutrition after school, the interventions consisted of motivating school-age children, parents, or people responsible for children to lead healthy lifestyles after finishing the school day or on holidays. The main focus for this strategy was motivation to stimulate the will to a healthy lifestyle change. Organized educational sessions were carried out providing support to parents in terms of healthy eating, self-efficacy to change specific behaviors, and taking care of the practice of physical activity for the child. Games were also played to overcome different barriers that children could present and thus remain constantly active, avoiding a 
sedentary lifestyle in school-age children, as also reported by Annesi et al., (2016) [46].

\subsection{Typical outcomes measured in FNE interventions}

The FNE interventions were beneficial in improving knowledge and lifestyle practices in school-age children. However, very few achieved positive changes in nutritional status $[17,19]$. This was regardless of the type of intervention and the time duration of the interventions. The educational interventions to promote healthy eating were carried out to increase knowledge on healthy eating habits in which FNE sessions were constructed using different didactic materials such as talks, workshops, visits to the food market, videos, games, etc.

A study in Mexico in 2015, on the impact of an educational intervention program, conducted educational sessions for parents of 10 obese school-age children aged 7 to 11 years [17]. Diferent didactic tools were being used in the interventions to improve knowledge about healthy lifestyle practices. The results of the evaluation identified that the educational intervention program caused a significant change in the attitude of the responsible adult about school obesity. In this article, Díaz et al., (2015) reported that knowledge of parents about healthy eating and the importance of preventing overweight and obesity was improved by choosing better food offers [17].

In Mexico, a study developed by Ríos-Pérez et al., (2015) with 920 overweight or obese school-age children performed an educational intervention through training on healthy lifestyles, for a year [33]. At the end of the intervention, the school-age children were able to increase their knowledge of healthy eating and physical activity in a higher proportion than children with normal weight. They were evaluated using instruments designed for each topic to assess the level of learning acquired from healthy eating and physical activity after the intervention. Authors showed that FNE has a significant effect in improving healthy behaviors in school-age children.

Martínez Trescastro (2016) in Spain evaluated 28 school-age children in the context of an FNE intervention [8]. Their results were positive responses in the students since more than 70 percent acquired knowledge of healthy eating and healthy lifestyle practices. After two years, the consumption of industrialized products was reduced and fruits were the most consumed food. They concluded that the FNE intervention produces significant changes, improving knowledge and increasing the consumption of healthy foods [8].

Regarding eating habits, the identified interventions applied different tools to know the eating behaviors in school children, they used food frequency questionnaires, 24-hour dietary recalls, child-eating behavior questionnaires, and facial hedonic scales to know acceptance of the school lunch. Some of the characteristics that could be observed in the eating behaviors in the school-age children in the studies, is that the diet is usually varied and this depends on the sociodemographic characteristics of the children. For example, children from rural areas tend to consume traditional foods typical of their culture, and children from urban areas have access to processed foods, sugary drinks, or fast food. It should be noted that the evaluated dietary patterns included assessing the habit of having breakfast, lunch, and dinner [28,37].

González-González et al., (2016) in a study carried out in Spain with 1142 school-age children, to assess the eating patterns in elementary school, a questionnaire was applied to investigate and fully understand the schoolchild's diet [28]. The result was that food preference is an important factor in children when choosing a specific food. In addition, it was found that cereals were the most consumed food (92.8 percent). Vegetable consumption was low (35.4 percent). It should be noted that adequate nutrition is essential for the intellectual development of school-age children since it avoids the risks of suffering from 
chronic non-communicable diseases [28].

Regarding the nutritional evaluations, weight, height, body mass index (BMI), waist index, hip index, and skinfolds were measured in several interventions. The nutritional status of the participants was determined to classify them as having overweight, obesity, or normal weight according to the child growth standards of the World Health Organization [47]. Nutritional assessments are included as an important dimension of the evaluation of FNE interventions. Several articles report the results of knowledge of nutrition, as well as food intake and nutritional status in the FNE intervention periods in schools. One of them is the study carried out by Aparco et al., (2017) in Peru [12]. The objective of the intervention was to determine the impact of an FNE program in school-age children from first to fourth grade on BMI, knowledge of nutrition, and eating patterns. The results found in the 696 school-age children revealed that the intervention carried out in the first year showed a positive impact on the improvement of knowledge in nutrition (OR: 1,46; 95 percent: CI: 1,17-1,81), the implementation also improved the eating pattern in all food groups except vegetable. However, this intervention failed to reduce the BMI Z-score [12].

Another study carried out in Mexico aimed to know the effect that an FNE program in schools has on the eating habits and nutritional status of school-age children [22]. The intervention was carried out in 35 children for 9 months. The results detailed that the school-age children positively improved their eating pattern, especially the consumption of sugary drinks was reduced at the end of the intervention. However, in the anthropometric characteristics, an increase in height, body weight, and waist circumference was observed, the BMI was maintained during the intervention [22].

A study carried out in Spain on an FNE program evaluated 79 school-age children aged 6 to 8 years intending to improve their nutritional status and eating habits. The intervention did not show statistically significant associations. However, for the body mass index variable after the intervention, the levels of normal weight, overweight, and obesity improved. Concerning eating habits, the need to improve the diet in school-age children was demonstrated, since an impoverished consumption of food groups was found. This intervention shows that it is important to implement FNE programs in schools to improve knowledge and practices of a healthy lifestyle from an early age to achieve optimal growth and development [29]. 
Table 1. Descriptive data of the selected studies.

\begin{tabular}{|c|c|c|c|}
\hline Author, year & Country & Objective & Sample size \\
\hline Aparco et al., 2017 [12] & Peru & $\begin{array}{l}\text { To determine the impact, in } \\
\text { the first year, of an } \\
\text { educational-motivational } \\
\text { intervention called "Jugando" } \\
\text { on body mass index, } \\
\text { knowledge about feeding, } \\
\text { levels of physical activity and } \\
\text { food consumption patterns in } \\
\text { schoolchildren from 1st to } 4 \text { th } \\
\text { grade from four primary } \\
\text { schools in Cercado de Lima. }\end{array}$ & 696 \\
\hline Álvarez et al., 2017 [13] & Ecuador & $\begin{array}{l}\text { To determine the association } \\
\text { of eating habits and } \\
\text { nutritional status in eight- to } \\
\text { nine-year-old schoolchildren } \\
\text { from the city of Azogues, } \\
\text { Ecuador }\end{array}$ & 315 \\
\hline Ávila et al., 2018 [14] & Mexico & $\begin{array}{l}\text { To determine the classification } \\
\text { of behaviors and eating habits } \\
\text { of school children through the } \\
\text { exploration of eleven } \\
\text { dimensions. }\end{array}$ & 243 \\
\hline Almeida et al., 2019 [15] & Mexico & $\begin{array}{l}\text { To determine differences in } \\
\text { eating patterns, obesity and } \\
\text { overweight in schoolchildren } \\
\text { from public and private } \\
\text { sectors in the } \\
\text { Zacatecas-Guadalupe } \\
\text { Metropolitan Area of Mexico. } \\
\text { to evaluate associations }\end{array}$ & 372 \\
\hline $\begin{array}{c}\text { Altamirano and Nazar, } 2020 \\
\text { [16] }\end{array}$ & Chile & $\begin{array}{l}\text { between caregivers' infant } \\
\text { feeding attitudes and practices } \\
\text { versus the nutritional status of } \\
\text { children of Mapuche and } \\
\text { non-Mapuche origin. }\end{array}$ & 200 \\
\hline Díaz et al., 2015 [17] & Mexico & $\begin{array}{l}\text { To evaluate the impact of an } \\
\text { educational intervention } \\
\text { program on the change in } \\
\text { attitude towards school } \\
\text { obesity, and knowledge about } \\
\text { healthy eating, better eating } \\
\text { behaviors; increased physical } \\
\text { activity; practice of exercise } \\
\text { and the ability to sustain } \\
\text { incorporated changes. }\end{array}$ & 19 \\
\hline Azcorra et al., 2016 [18] & Mexico & $\begin{array}{l}\text { To describe the nutritional } \\
\text { status and growth patterns of } \\
\text { school children ( } 6 \text { to } 12 \text { years } \\
\text { of age) in three rural } \\
\text { communities in the state of } \\
\text { Yucatán, Mexico: Yotholín, } \\
\text { Xkanchakan and } \\
\text { Chikindzonot. }\end{array}$ & 144 \\
\hline Benítez et al., 2016 [19] & Mexico & $\begin{array}{l}\text { To evaluate the effectiveness } \\
\text { of an educational intervention } \\
\text { on the nutritional status and } \\
\text { the level of knowledge about } \\
\text { food patterns and physical } \\
\text { activity in schoolchildren. }\end{array}$ & 368 \\
\hline
\end{tabular}


Author, year

Bergel et al., 2017 [20]

Delgado et al., 2017 [21]

Briones et al., 2018 [22]

Encina et al., 2019 [23]

Espinosa et al., 2019 [24]

Flores et al., 2019 [25]

García et al., 2017 [26]

González and Díaz, 2015 [27]

González et al., 2016 [28]

González et al., 2017 [29]

\section{Country}

Argentina

Chile

Mexico

Chile

Mexico

Mexico

Mexico

Colombia

Spain

Spain

\section{Objective}

Sample size

To analyze the relationship between nutritional status and residence socio-environmental conditions in school-age

children from the Department of Villaguay, Entre Ríos, Argentina.

To relate the nutritional status with the levels of self-esteem and physical performance in schoolchildren between 8 and 10 years of age.

To evaluate the effects of the program of physical activity and nutritional education (CIMARRONES AFYN) on anthropometry and eating habits in school-age children. To compare eating behavior in schoolchildren from different schools according to nutritional status.

To assess genetic damage and eating habits of children with obesity and normal weight. To identify the waist circumference measurement area that best determines

childhood obesity, contrasted with obesity indicators.

To analyze the nutritional status and eating habits of Mexican indigenous schoolchildren, depending on their gender, age and community of origin. To determine family characteristics associated with nutritional status of school children in the city of Cartagena, Colombia.

To assess the dietary patterns of school-children in La

Mancha Centro (Ciudad Real), Spain.

To establish the levels of body mass indexes, degree of adherence to the

Mediterranean diet and self-concept in a sample of Primary Education students and to determine the possible physical-healthy and psychosocial differences after carrying out the "SportFruits" intervention program. 


\begin{tabular}{|c|c|c|c|}
\hline Author, year & Country & Objective & Sample size \\
\hline $\begin{array}{c}\text { Martínez and Trescastro, } 2016 \\
{[8]}\end{array}$ & Spain & $\begin{array}{l}\text { To evaluate the pilot } \\
\text { experience of the food and } \\
\text { nutrition education } \\
\text { intervention carried out at the } \\
\text { "La Serranica" Public School } \\
\text { of Aspe, Alicante (Spain), to } \\
\text { promote knowledge and } \\
\text { healthy eating habits. }\end{array}$ & 29 \\
\hline Martínez et al., 2017 [30] & Spain & $\begin{array}{c}\text { To describe the prevalence of } \\
\text { excess weight (overweight } \\
\text { and obesity) and its } \\
\text { association with the practice } \\
\text { of sports activity and lunch in } \\
\text { schoolchildren aged 6-12 } \\
\text { years. }\end{array}$ & 153 \\
\hline Martínez et al., 2016 [31] & Spain & $\begin{array}{l}\text { To estimate the prevalence of } \\
\text { overweight/obesity and } \\
\text { thinness in school-children } \\
\text { born between } 2007 \text { and } 2008 \\
\text { from Castilla-La Mancha, } \\
\text { Spain, in 2013-2015. }\end{array}$ & 1490 \\
\hline Mosquera et al., 2016 [32] & Colombia & $\begin{array}{l}\text { To determine the nutritional } \\
\text { status by anthropometry, } \\
\text { eating habits and iron status } \\
\text { in school-children aged nine } \\
\text { to eleven years old from a } \\
\text { public school in Valledupar, } \\
\text { Colombia. }\end{array}$ & 155 \\
\hline Ríos-Pérez et al., 2015 [33] & Mexico & $\begin{array}{l}\text { To evaluate the association of } \\
\text { expected learning in healthy } \\
\text { eating and physical activity } \\
\text { with anthropometric } \\
\text { indicators of obesity in urban } \\
\text { school-children in the state of } \\
\text { Hidalgo, Mexico. }\end{array}$ & 920 \\
\hline Sanabria et al., 2017 [34] & Paraguay & $\begin{array}{l}\text { To evaluate the degree of } \\
\text { acceptance and percentage of } \\
\text { adaptation to the nutritional } \\
\text { requirements of the school } \\
\text { lunch for boys and girls from } \\
\text { two public schools in } \\
\text { Asunción, Paraguay. }\end{array}$ & 102 \\
\hline Serral et al., 2019 [35] & Spain & $\begin{array}{l}\text { To analyze the association of } \\
\text { childhood overweight and } \\
\text { obesity in the city of } \\
\text { Barcelona, Spain according to } \\
\text { socioeconomic variables in } \\
\text { third-year primary school } \\
\text { students. }\end{array}$ & 3624 \\
\hline Shamah et al., 2017 [36] & Mexico & $\begin{array}{l}\text { To evaluate the effect of the } \\
\text { SaludArte service program on } \\
\text { nutrition education and food } \\
\text { assistance components, within } \\
\text { participating schools between } \\
2013 \text { and } 2015 \text {. }\end{array}$ & 1620 \\
\hline Togo et al., 2016 [37] & Mexico & $\begin{array}{l}\text { To compare the habitual } \\
\text { consumption of food by } \\
\text { children in an urban versus a } \\
\text { rural area in Arandas, Mexico. }\end{array}$ & 196 \\
\hline
\end{tabular}




\begin{tabular}{|c|c|c|c|}
\hline Author, year & Country & Objective & Sample size \\
\hline Varela et al., 2018 [38] & Colombia & $\begin{array}{l}\text { To develop a proposal for the } \\
\text { synthesis of the information } \\
\text { obtained from the Health } \\
\text { Habits Questionnaire related } \\
\text { to Childhood } \\
\text { Overweight/Obesity in } \\
\text { Colombia. }\end{array}$ & 239 \\
\hline Díaz et al., 2015 [39] & Spain & $\begin{array}{l}\text { To Evaluate the effect of an } \\
\text { intervention in nutrition and } \\
\text { physical activity (PA) on the } \\
\text { reduction of obesity in } \\
\text { schoolchildren. }\end{array}$ & 312 \\
\hline Gálvez Casas et al., 2015 [40] & Spain & $\begin{array}{l}\text { To analyze the level of quality } \\
\text { of life in relation to nutritional } \\
\text { status in a sample of primary } \\
\text { school children. }\end{array}$ & 298 \\
\hline $\begin{array}{l}\text { Fernández-García et al., } 2019 \\
\text { [41] }\end{array}$ & Spain & $\begin{array}{l}\text { To Describe the effect of } \\
\text { overweight and obesity in } \\
\text { eleven-year-old } \\
\text { schoolchildren on tests } \\
\text { assessing strength, both lower } \\
\text { and upper extremity, as well } \\
\text { as speed. }\end{array}$ & 423 \\
\hline $\begin{array}{c}\text { Barja-Fernández et al., } 2019 \\
\text { [42] }\end{array}$ & Spain & $\begin{array}{l}\text { To determine the quality of } \\
\text { the quality of the dietary } \\
\text { pattern and the practice of } \\
\text { physical activity in primary } \\
\text { and secondary and secondary } \\
\text { schoolchildren in Galicia and } \\
\text { its relationship with sex, } \\
\text { educational stage and } \\
\text { adiposity and the degree of } \\
\text { adiposity, in order to assess } \\
\text { the need to reinforce the to } \\
\text { assess the need to reinforce } \\
\text { the current intervention } \\
\text { strategies for the strategies for } \\
\text { the promotion of healthy } \\
\text { lifestyles. }\end{array}$ & 662 \\
\hline Bibiloni et al., 2017 [43] & Spain & $\begin{array}{l}\text { To Evaluate the results of a } \\
\text { nutrition education program } \\
\text { developed with local } \\
\text { resources to improve diet } \\
\text { quality and reduce the } \\
\text { prevalence of overweight and } \\
\text { obesity in the population. }\end{array}$ & 1199 \\
\hline
\end{tabular}

\section{Discussion}

Overall, the results found in this review, most of the interventions in FNE improve knowledge after the implementation of the programs, which shows a positive response. The FNE interventions are positive, since they guide healthy lifestyles, modify eating behaviors and learn practices or knowledge in food and nutrition. In addition, the evaluated studies of interventions that involve more than one aspect studied, such as FNE, increased physical activity, participation of parents, teachers, and transformation of healthy schools and community environments, cause positive physical changes by improving nutritional status and knowledge. It is necessary to continue implementing FNE programs to contribute to the health of school-age children and improve their lifestyles. 
The results of the present review are consistent with other available reviews. For example, a review conducted in Brazil using 13 articles published between 2000 and 2011 showed that FNE improves the knowledge of nutrition and food choices of school-age children [48]. However, the studies that involved anthropometric measurements did not have changes in their nutritional status [48,49]. Despite this, working in schools to achieve positive changes in children's health and that prevention remains the first step in combating overweight and obesity. The results on the FNE in the present review are similar to a review performed in Spain based on 17 articles [50]. Primary prevention interventions were shown to positively influence healthy lifestyles, compared to other interventions that are capable of reducing weight in school-age children [50]. Another review carried out in Peru on the effectiveness of an educational intervention to promote healthy eating in school-age children evaluated 10 articles [51]. They reported that FNE interventions have a high probability of improving knowledge about healthy lifestyles in children [51]. It seems that educational interventions have a greater impact on knowledge and attitude towards healthy eating. Therefore, surveillance systems in schools must incorporate a variety of indicators and not just anthropometric markers.

The duration of the interventions is fundamental to achieve success in an FNE intervention. If a study fails to show changes, for example, in the weight of school-age children, it may be that this intervention was carried out in a short period and does not necessarily reflect problems with the effectiveness of the FNE intervention. Long-term interventions are associated with higher changes in the lifestyles of school-age children, including nutritional status $[12,19,52,53]$. It is essential to extend the time frame of FNE interventions to achieve stronger and more sustainable changes over time. In addition, FNE must have a comprehensive approach, considering the environment and all actors in schools such as parents, teachers, and the community.

Figure 2 shows a proposed conceptual framework for the implementation of FNE against overweight and obesity in schools. The results can contribute to the implementation of nutritional interventions within the school curriculum, with the help of ministries such as ministries of education, health, social development or agriculture to achieve a positive impact on the learning of healthy lifestyles in school-age children. Finally, the evidence shows that comprehensive FNE interventions such as physical activity, participation of parents, teachers, community environment, and transformation of healthy schools, cause positive effects on nutritional status, improve knowledge, and contribute to chronic noncommunicable disease prevention.

The findings of this review should be analyzed considering some limitations. A limitation of this study was that a systematic review and meta-analysis were not performed to research statistical conclusions. One strength of this review was the compilation of high quality articles across country contexts to understand the range of FNE intervention modalities being used in school programs. Interventions from an early age have been shown to have a positive effect on increasing knowledge and improving lifestyle. 


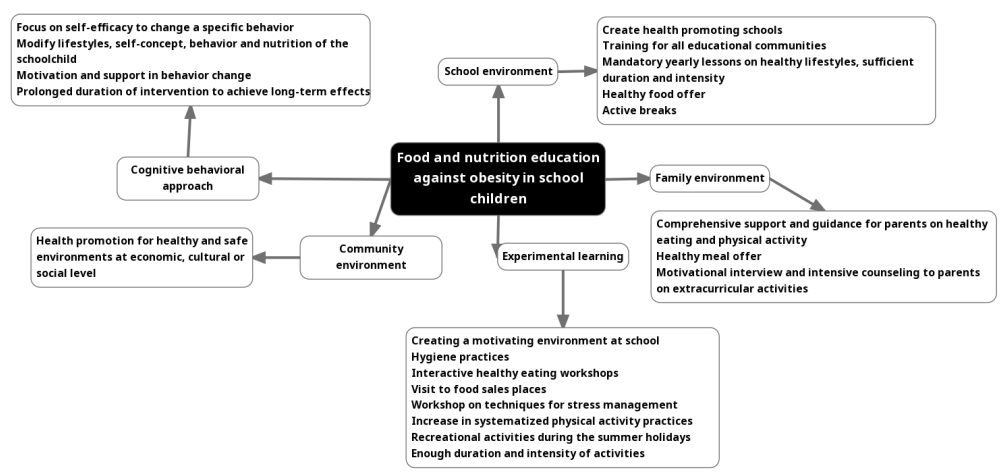

Figure 2. Conceptual model for FNE against overweight and obesity in elementary schools. Source: own interpretation based on scoping and critical review.

\section{Conclusions}

In conclusion, FNE interventions come in many varieties regardless of context. However, they all have several common attributes for addressing the nutrition of school-aged children. Understanding the relative impacts of different types of FNE interventions on child health and nutrition, by context, may be important follow-up work to inform policy and programming investment for countries wishing to achieve improved population-level health and nutrition.

Author Contributions: Conceptualization, AL-Q., LO., IR-C. and VV.; methodology, IR-C., AL-Q., and LO.; writing - original draft preparation, AL-Q. and LO.; writing-review and editing, IR-C, FF., VV., RA., AB., and SK..; All authors have read and agreed to the published version of the manuscript.

Funding: This research was funded by authors.

Acknowledgments: The authors thank the School of Nutrition and Dietetics of the University of Panama and its teachers. AB was supported by the Ministry of Science and Higher Education of the Russian Federation within the framework of state support for the creation and development of World-Class Research Centers "Digital Biodesign and Personalized Healthcare N $075-15-2020-926$ ".

Conflicts of Interest: The authors declare no conflict of interest.

\section{Abbreviations}

The following abbreviations are used in this manuscript:

FNE Food and Nutrition Education

BMI Body Mass Index

\section{References}

1. WHO. Report of the commission on ending childhood obesity; World Health Organization: Geneva, Switzerland, 2016; pp. 1-68.

2. Rivera, J., González, T., Pedraza, L., Aburto, T., Sánchez, T. Martorell, R. Childhood and adolescent overweight and obesity in Latin America: A systematic review. Lancet Diabetes Endocrinol 2014, 2, 321-332.

3. PAHO. Health Situation in the Americas: Core Indicators 2017; Pan American Health Organization: Washington D.C., US, 2017; pp. $1-20$.

4. Monteiro, C., Moubarac, J., Cannon, G., Ng, S., Popkin, B. Ultra-processed products are becoming dominant in the global food system. Obes Rev 2008, 14, 21-28.

5. Ruel, M., Alderman, H. Nutrition-sensitive interventions and programmes: How can they help to accelerate progress in improving maternal and child nutrition?. Lancet 2013, 382, 536-551.

6. Martin, A., Booth, J., Laird, Y., Sproule, J., Reilly, J., Saunders, D. Physical activity, diet and other behavioural interventions for improving cognition and school achievement in children and adolescents with obesity or overweight. Cochrane Database Syst Rev $20181,1-185$.

7. Montenegro, E., Salinas, J., Parra, M., Lera, L., Vio, F. Evaluation of a nutrition education intervention in teachers and students in preschool and primary schools in los Andes, Chile. Arch Latinoam Nutr 2014, 64, 182-191. 
8. Martínez, A., Trescastro, E. Development of a programme about Food and Nutrition Education in school children in the State School "La Serranica” in Aspe (Alicante): A pilot experience. Rev Esp Nutr Hum Diet 2016, 20, 97-103.

9. Hughes, S., Power, T., Beck, A., Betz, D., Goodell, L., Hopwood, V., Jaramillo, A., Lanigan, J., Martinez, A., Micheli, N., Olivera, Y., Overath, I., Parker, L., Ramos, G., Thompson, Y. Johnson, S. Short-term effects of an obesity prevention program among low-income Hispanic families with preschoolers. J Nutr Educ Behav 2020, 52, 224-239.

10. Cabello, M., Zúñiga, J. Aspectos intrapersonales y familiares asociados a la obesidad: un análisis fenomenológico. Ciencia UANL 2007, 10, 183-188.

11. García, M. Cómo personalizar la educación. Una solución de futuro. Rev Complut de Educ 2008, 19, $227-229$.

12. Aparco, P., Bautista W., Pillaca, J. Impact evaluation of educational-motivational intervention "como jugando" to prevent obesity in school children of cercado de lima: Results in the first year. Rev Peru Med Exp Salud Publica 2017, 34, 386-394.

13. Álvarez, R., Cordero, G., Vásquez, M., Altamiro, L., Gualpa, M. Eating habits: their relationship with the nutritional status of schoolchildren in the city of Azogues, Ecuador. Rev Ciencias Médicas 2017, 21, 852-859.

14. Ávila, H., Gutiérrez, G., Martínez, M., Ruíz, J., Guerra, J. Behavior and eating habits in school students. Horiz Sanitario 2018, 17, 217-225.

15. Almeida, C., Gutiérrez, A., Ruiz, D., García, G. Food patterns and school overweight-obesity. Comparative study of the public and private of education, Zacatecas-Guadalupe Metropolitan Zone. RESPYN 2019, 18, 9-16.

16. Altamiro, N., Nazar, G. Attitudes and feeding practices of primary caregivers of Mapuche and non-Mapuche schoolchildren according to nutritional status. Rev Chil Nutr 2020, 47, 89-96.

17. Díaz, M., Larios, J., Mendoza, M., Moctezuma, L., Rangel, V., Ochoa, C. Intervención educativa en la obesidad escolar. Diseño de un programa y evaluación de la efectividad. Rev Cubana Aliment Nutr 2015, 25, 341-355.

18. Azcorra, H., Vásquez, A., Baqueiro, J., Salazar, J. Growth and nutritional status of school age children of three communities from Yucatan, Mexico. Arch Latinoam Nutr 2016, 66, 135-141.

19. Benítez, V., Vázquez, I., Sánchez, R., Velasco, R., Ruiz, S., Medina, M. Educational intervention on nutritional status and knowledge on diet and physical activity in school children. Rev Enferm Inst Mex Seguro Soc 2016, 24, 37-43.

20. Bergel, M., Cesani, F., Oyhenart, E. Contexts of child malnutrition in the district of Villaguay, Entre Ríos, Argentina. A multivariate analysis. Plos One 2017, 12, 1-13.

21. Delgado, P., Caamaño, F., Jerez, D., Cofré, A., Osorio, A., Campos, C., Guzmán, I., Martínez, C., Carcamo, J. Obesity, self-esteem and fitness in students. Rev Fac Med 2017, 65, 43-48.

22. Briones, R., Gómez, L., Ortiz, M., Rentería, I. Effect of a physical activity program and nutritional education to prevent sugar sweetened beverages consumption and development of obesity among school-age children in Tijuana, Mexico. Rev Esp Nutr Hum Diet 2018, 22, 235-242.

23. Encina, C., Gallegos, D., Espinoza, P., Arredondo, D., Palacios, K. Comparison of food behavior among school children by educational establishment and nutritional status. Rev Chil Nutr 2019, 46, 254-263.

24. Espinosa, M., Ortega, L., Pérez, B., Marqués, A., Baños, M. Evaluation of genetic damage and eating habits in children with normal weight and obesity in school age. Nutr Hosp 2019, 36, 309-314.

25. Flores-Olivares, Luis Alberto, De-León-Fierro, Lidia G., Jiménez-Ponce, Brenda Paola,, Ortíz-Rodríguez, Briseidy. Measurement of waist circumference at four sites and its relationship with obesity indicators in children of 6 to 11 years. CienciaUAT 2019, 13, 18-27.

26. García, C., González, E., Meléndez, J., García, P., García, C. A study of nutritional status and dietary habits among schoolchildren from different indigenous communities within the municipality of Ixhuatlán de Madero, State of Veracruz (Mexico). Arch Latinoam Nutr 2017, 67, 238-250.

27. González, Y., Díaz, C. Family characteristics associated with the nutritional status of schools children in the city of Cartagena. Rev salud pública 2015, 17, 836-847.

28. González, A., Falero, M., Redondo, O., Muñoz, A. Food habits of the school population from La Mancha-Centro Health Area (Ciudad Real). An Pediatr 2016, 84, 133-138.

29. González, G., Zurita, F., Puertas, P., Chacón, R., Espejo, T., Castro, M. Education for health: implementation of the program "Sportfruits" in schools of Granada. SPORT TK 2017, 6, 137-146

30. Martínez, A., Aix, J., Martínez, J., Leyva, B. Evaluation of physical fitness, sports and nutritional status of children aged 6 to 12: a pilot study. Rev Esp Nutr Hum Diet 2017, 21, 3-10.

31. Martínez, J., Pozuelo, D., Solera, M., González, A., Martínez, V., Sánchez, M., Martínez, D. Trends in underweight and excess of weight prevalence in a cohort of 4-to 6-year-old schoolchildren from Castilla-La Mancha. Nutr Hosp 2016, 33, 1299-1304.

32. Mosquera, I., Mosquera, M., De Armas, L., Brito, Y. Nutritional status and eating habits of children in a Public school in Valledupar. Rev Méd Risaralda 2016, 22, 42-48.

33. Ríos-Pérez, F., Cerón-Obregón, N., Gerardo-Olguín, I., López-Rodríguez, G., Denova-Gutiérrez, E.,, Galván, M. Aprendizajes de alimentación saludable y actividad física en escolares con sobrepeso u obesidad. ICSA 2015, 4, 1-7.

34. Sanabria, M., Frutos, D., Preda, J., Gónzalez, L., Cornelli, P. Adequacy and acceptance of school lunches in two public schools from Asunción. Pediatr 2017, 44, 126-135.

35. Serral, G., Bru, R., Sánchez, F., Ariza, C., Grupo de evaluación del proyecto POIBA. Overweight and childhood obesity according to socioeconomic variables in third grade school-age children in the city of Barcelona. Nutr Hosp 2019, 36, $1043-1048$. 
36. Shamah, T., Cuevas, L., Gómez, L., Morales, M., Gómez, I., Robles, M., Hernández, M. Effects of SaludArte program in feeding and nutrition components in school children in Mexico City. Salud Publica Mex 2017, 59, 62-629.

37. Togo, Y., Romero, E., Vásquez,E., Palencia, C., Sabido, E. Comparison of foodconsumption in children living in an urban area and a rural population in Arandas, Mexico. Arch Latinoam Nutr 2016, 66, 287-293.

38. Varela, M., Ochoa, A., Tovar, J. Measuring eating habits and physical activity in children: Synthesis of information using indexes and clusters. Rev Mex de Trastor 2018, 9, 264-276.

39. Díaz X., Bastías C., Morales C., Salas C., Moral P. Effect of a healthy eating and physical activity intervention program on chilhood obesity. Nutr Hosp 2015, 32, 110-117.

40. Gálvez Casas A., Guillamón A., García-Cantó E., Rodríguez P., Pérez-Soto J., Tarraga L., Tarraga P. Nutritional status and health related life quality in school children from the southeast of Spain. Nutr Hosp 2015, 31, 737-743. $\mathrm{F}$

41. ernández J., Castillo A., Onetti W. Influence of overweight and obesity on strength in childhood. Nutr Hosp | 2019, 36, 1055-1060. $\mathrm{F}$

42. Barja-Fernández S., Pino Juste M., Portela Pino I., Leis R. Evaluation of food habits and physical activity in Galician students. Nutr Hosp 2020, 37, 93-100.

43. Bibiloni M., Fernández-Blancoc J., Pujol-Planad N., Martín-Galindoc N., Fernández-Vallejoc M., Roca-Domingod M., ChamorroMedinae J., Tur J. Improving diet quality in children through a new nutritional education programme: INFADIMED. Gac Sanit 2017, 31, 472--477.

44. Nyberg, G., Norman, Å., Sundblom, E., Zeebari, Z., Elinder, L. Effectiveness of a universal parental support programme to promote health behaviours and prevent overweight and obesity in 6-year-old children in disadvantaged areas, the healthy school start study II, a cluster-randomised controlled trial. Int J Behav Nutr Phys Act 2016, 13, 1-14.

45. Yang, Y., Kang, B., Lee, E., Yang, H., Kim, H., Lim, S., Lee, J., Lee, S., Suh, B., Yoon, K. Effect of an obesity prevention program focused on motivating environments in childhood: A school-based prospective study. Int J Obes 2017, 41, 1027-1034.

46. Annesi, J., Smith, E., Walsh, M., Mareno, N., Smith, R. Effects of an after-school care-administered physical activity and nutrition protocol on body mass index, fitness levels, and targeted psychological factors in 5- to 8-year-olds. Transl Behav Med 2016, 6, 347-357.

47. Child Growth Standards. Available online: http://www.who.int/childgrowth/en/ (accessed on 16 Oct 2020).

48. Ramos, F. Santos, L., Reis, A. Educação alimentar e nutricional em escolares: Uma revisão de literature. Cad Saude Publica 2013, 29, 2147-2161.

49. Polonsky, H., Bauer, K., Fisher, J., Davey, A., Sherman, S., Abel, M., Hanlon, A., Ruth, K., Dale, L., Foster, G. Effect of a breakfast in the classroom initiative on obesity in urban school-aged children: A cluster randomized clinical trial. JAMA Pediatr 2019, 173, 326-333.

53. De La Fuente, M. C., Cervera, G. A. Review of school-based interventions for primary prevention of childhood obesity. RECIEN 2018, 15, 19-35.

51. García, K., Mejía, B. Efectividad de una intervención educativa para la promoción de alimentación saludable en niños en etapa escolar. BSc. Thesis, Family and Community Health Nursing Specialist, Universidad Privada Norbert Wiener, Lima, Perú. 08 July 2018.

52. Centeio, E., McCaughtry, N., Moore, E., Kulik, N., Garn, A., Martin, J., Shen, B., Somers, C., Fahlman, M. Building healthy communities: A comprehensive school health program to prevent obesity in elementary schools. Prev Med 2018, 111, $210-215$.

53. Vogeltanz, N., Holm, J. Changes in body mass index during a 3-year elementary school-based obesity prevention program for american indian and white rural students. Health Educ Behav 2018, 45, 277-285. 